\title{
1 Structure and development of the metapleural gland in \\ 2 Technomyrmex vitiensis
}

3 Pavel Pech ${ }^{1} \&$ Johan Billen ${ }^{2}$

$4{ }^{1}$ Faculty of Science, University of Hradec Králové, Rokitanského 62, 50003 Hradec

$5 \quad$ Králové, Czech Republic. E-mail: pavelpech1@centrum.cz (corresponding author)

$6 \quad{ }^{2}$ KU Leuven, Zoological Institute, Naamsestraat 59, box 2466, B-3000 Leuven, Belgium.

$7 \quad$ E-mail: johan.billen@kuleuven.be

\section{Abstract}

9 We studied the internal and external appearance of the metapleural gland in the 5 castes

10 of Technomyrmex vitiensis. All castes do possess the gland, but with a clear gradient from

11 queens (most developed gland), via intercastes, workers and wingless males to winged

12 males (least developed). Also the size and the shape of the atrium differs among castes

13 along the same gradient. The presence of a more developed gland in wingless males than 14 in winged males may be linked with the much longer longevity of the former. The number 15 of secretory cells in $T$. vitiensis is the lowest among ants known so far. The functional 16 meaning of this is not yet known, and calls for a functional study of the gland's secretion.

18 Among the various social insect groups, ants are known for having the largest number of exocrine glands, with 84 different glands distinguished so far (Billen and Šobotník 2015). In this impressive exocrine equipment, the metapleural gland is of special importance, as it

21 represents a neoformation that is only found in the Formicidae (Brown 1968). The gland is present in the majority of species, although it is absent in some social parasites and 
23 arboreal ants, while it is also often absent in males (Brown 1968; Hölldobler and Engel-

24 Siegel 1984). The metapleural gland is a paired structure situated in the posterior region of the thorax. Each gland consists of secretory cells, each cell opening into a sac-like atrium through an accompanying duct cell. The metapleural gland secretion is believed to have an antimicrobial and fungicidal effect and should substantially contribute to ant immunity (Maschwitz et al. 1970; Maschwitz 1974; Beattie et al. 1986; Tragust 2016).

In this paper, we document the metapleural gland development in all castes of the

30 dolichoderine ant Technomyrmex vitiensis Mann, 1921. T. vitiensis is probably of SouthEast Asian origin, but has recently been found to be widespread in greenhouses across the world (Bolton 2007; Pospischil 2011). The species nests in various materials and spaces such as in leaf litter, under stones, on vegetation, in twigs or under leaves. It tends homopterans for honeydew and preys on small arthropods (Bolton 2007), but its biology in terms of brood care, colony structure and dispersal is rather poorly known and is considered to be similar to its more intensively studied relatives from the Technomyrmex albipes species group such as T. brunneus Forel, 1895, T. pallipes (Smith, 1876) and T. difficilis Forel, 1892. As in several other Technomyrmex species, several castes are known in T. vitiensis: large, initially winged queens, ergatomorph wingless intercastes, workers, winged males and ergatomorph wingless males (Pech and Bezděk 2016).

\section{Material and Methods}

Individuals used for this study were taken from a colony fragment collected in the Prague Zoo (Czech Republic, Praha, 50 $7^{\prime} \mathrm{N}, 14^{\circ} 24^{\prime} \mathrm{E}$ ) and in the botanical garden of Charles University (Czech Republic, Praha, 504' N, 14² 25' E) in October and November 2015.

For histological examination, the posterior thorax half of winged queens and intercastes, workers, and winged and wingless males (5 individuals of each) was fixed in cold $2 \%$ 
47 glutaraldehyde in a $0.05 \mathrm{M}$ Na-cacodylate buffer. After postfixation with $2 \%$ osmium

48 tetroxide in the same buffer, tissues were dehydrated in a graded acetone series and 49 embedded in Araldite. Serial semithin sections of $1 \mu \mathrm{m}$ were made with a Leica EM UC6 50 ultramicrotome, stained with methylene blue and thionin, and viewed in an Olympus BX-51

51 microscope. To estimate the number of secretory cells, we first measured the average cell 52 diameter in each caste. For each caste, we then counted the cumulative number of cells 53 occurring on serial sections through the posterior thorax at an interval equivalent to the cell 54 diameter in that caste. Atrium volume was calculated using the formula of an ellipsoid (4/3 $55 \times \pi \times L \times W^{2}$, with $L=$ length and $W=$ width), as this most closely resembles the atrium 56 shape.

57 For scanning microscopy, the posterior thorax part of 1-3 specimens of each caste were 58 critical point dried in a Balzers CPD 030 instrument, coated with gold and examined in a 59 JEOL JSM-6360 scanning microscope.

60 The statistical differences of cell numbers and diameters as well as atrium measurements

61 among castes were tested using a Kruskal-Wallis test with the following post-hoc 62 comparisons. We performed our calculations using both glands of each individual 63 separately as well as using the means of both glands together, as glands of the same 64 individual are likely not independent. As the results of both analyses were very similar, only 65 the results from the larger data set are presented, providing a better image of the variability of gland morphology.

\section{Results}

68 As in other dolichoderine ants (Yek and Mueller 2011), the paired metapleural gland of

69 Technomyrmex vitiensis corresponds with the 'one-chamber design', in which the 70 secretory cells open directly into a sclerotized atrium, that in turn opens to the outside. The 
71 gland belongs to class-3 according to the standard classification by Noirot and Quennedey 72 (1974), which means that each secretory cell releases its secretory products through its

73 own accompanying duct cell. The junction between both cells is formed by the 'end apparatus', which functions as a draining device to lead the secretory products from the secretory cell into the duct cell. This general anatomical organization is found in the 5 castes, although with considerable size differences (Figs 1,2A). The number of secretory cells, expressed per side for one gland, decreases in the following order: queens $(26.9 \pm$ 4.9 cells, $n=8$ glands, Fig. 1A), intercastes $(16.8 \pm 2.6$ cells, $n=8$ glands, Fig. 1B), workers $(10.8 \pm 2.6$ cells, $n=6$ glands, Fig. $1 C)$, wingless males $(4.3 \pm 0.8$ cells, $n=6$ glands, Fig. 1D) and winged males $(1.9 \pm 1.0$ cells, $n=10$ glands, Fig. $1 E)(H=35 ; p<0.01)$ (Table 1). Also the size of the spherical secretory cells differs significantly $(H=11.95$; $p=0.0178$ ) (Table 1) with a diameter that ranges between 25 and $29 \mu \mathrm{m}$ (Fig. 2B).

In all five castes, the duct cells open into the heavily sclerotized atrium through a kind of sieve plate. When transversally sectioned, the number of ducts in this region can be used as a good indication for the corresponding number of secretory cells (Figs 1F-I). The rigid atrium wall has a thickness around $10 \mu \mathrm{m}$, which is comparable to the thickness of the thoracic exoskeleton. The size of the atrium, however, is different between castes $(H=33.9$; p <0.01) (Table 1, Fig. 2C). Queens have the largest atrium (approx. $80 \times 65 \mu \mathrm{m}$ ), followed by intercastes (approx. $75 \times 55 \mu \mathrm{m}$ ), workers (approx. $60 \times 40 \mu \mathrm{m}$ ), wingless males (approx. $45 \times 25 \mu \mathrm{m}$ ) and winged males (approx. $30 \times 15 \mu \mathrm{m}$ ). Although the atrium shape is ellipsoid, it varies from more rounded in queens (length/width ratio around 1.2) to more elongated in winged males (length/width ratio around 2) $(H=20.23 ; p<0.01)$ (Table 1, Fig. 2D).

The external opening of the gland is clearly visible in all castes. In the female castes, it appears as an ovoid chamber of roughly $75 \times 55 \mu \mathrm{m}$ in queens and $60 \times 40 \mu \mathrm{m}$ in intercastes and workers, while the male castes have a circular opening with a diameter 
around $40 \mu \mathrm{m}$ in wingless males and $30 \mu \mathrm{m}$ in winged males (Fig. 3). Stiff hairs with a length of 20-30 $\mu \mathrm{m}$ line the outer margin of the gland opening and project towards the opposite side, thus giving the opening a lattice-like appearance, which is more pronounced in the three female than in the two male castes (Fig. 3). Although scanning microscopy best reveals these margin-lining hairs, similar hairs also occur inside the atrium in all castes except the winged males (shown only for queens in Fig. 1A).

\section{Discussion}

Our examination of both internal (histology) and external structure (scanning microscopy) shows that all five castes of Technomyrmex vitiensis have a metapleural gland, although with a clear gradient from queens (most developed) via intercastes, workers and wingless males to winged males (least developed). This gradient is reflected in the number and size of the secretory cells, the size of the atrium and the size of the external opening of the gland.

The two most commonly listed functions for the metapleural gland are the production of antibiotic substances and chemical defence, although other functions may also be possible (Yek and Mueller 2011). The large opening of the gland to the exterior near the implantation of the hindlegs allows free release of the antibiotic secretion, which is then distributed over the body by leg grooming. The atrium often contains stiff hairs that act as dispenser bristles that guide the secretion to the outside (Hölldobler and Engel-Siegel 1984). An elegant study by Fernández-Marín et al. (2006) confirms the general antibiotic nature of the secretion, but shows that ants actively increase grooming and hence distribution of secretion when the degree of infection is higher. Chemical defence is known in some southeast Asian Crematogaster species, in which the metapleural gland is hypertrophied with a very large atrium and more than 700 secretory cells per side (Billen et 
121 al. 2011). The much smaller gland in T. vitiensis makes such defensive function not very 122 plausible, and may rather assume that the gland serves its main role of producing 123 antibiotics. This, however, remains at the hypothetical level as no functional study on the 124 metapleural gland secretion has been done so far.

Most research on metapleural gland morphology has been done in the worker caste, in which a correlation has been reported between gland size, as expressed by the number of secretory cells, and body size. This correlation exists both intraspecifically in polymorphic species as leaf-cutting ants (Schoeters and Billen 1993; Bot and Boomsma 1996), as well as between species (Angus et al. 1993). Among all species for which information on metapleural gland cell numbers are available, $T$. vitiensis very much ranks at the low end of the spectrum as its workers with only $10.8 \pm 2.6$ secretory cells per side are even below Aneuretus simoni, that with 14 cells had the lowest number among workers of 44 species covering all major ant subfamilies (Hölldobler and Engel-Siegel 1984). Cell counts for Dolichoderinae in this paper are only available for Conomyrma bicolor (125 cells) and Iridomyrmex purpureus (317 cells). Fanfani and Valcurone Dazzini (1991) studied the metapleural gland of 6 dolichoderine species, and report they have large glands. The external orifice of the gland in Dolichoderinae is even larger than that of other subfamilies (Maschwitz 1974; Fanfani and Valcurone Dazzini 1991). Why T. vitiensis workers have such small metapleural glands remains an open question. It has been reported that the gland is reduced or absent in some arboreal species (Hölldobler and Engel-Siegel 1984), although T. vitiensis is not a true arboreal ant (Bolton 2007). It prefers to nest in plant cavities and under leaves, at least in greenhouses (Oettler and Heinze 2009; Pech and Bezděk 2016).

Among the various castes in $T$. vitiensis, queens clearly have larger metapleural glands, which is line with the few other species for which gland size in queens and workers has been compared. These data show the queens to have 2-3 times more cells than workers, 

as reported by Hölldobler and Engel-Siegel (1984) for Onychomyrmex hedleyi (102 vs 36), Pheidole embolopyx (65 vs 31), Solenopsis fugax (178 vs 82) and Nothomyrmecia macrops (439 vs 272), and by Angus et al. (1993) for Myrmecia gulosa (4823 vs 1920) and M. urens (381 vs 184). The latter authors speculate that queens have more developed metapleural glands because they have to make the brood chamber as aseptic as possible. The intercastes of $T$. vitiensis are also intermediate between queens and workers in terms of their metapleural gland development. Intercastes are similar in body size to workers, but have considerably more ovarioles (Oettler and Heinze 2009), which may link their more developed metapleural gland rather with their higher egg-laying capacity.

Absence or reduced development of the metapleural gland in males was already noticed by Brown (1968) and Hölldobler and Engel-Siegel (1984), and has been interpreted by their short live and hence low contribution to nest sanitation (Stürup et al. 2014). In a number of species with high male/worker ratios and/or males that stay longer in the nest, however, males do have larger metapleural glands, while also a secondary function in sex pheromone production may be possible (Hölldobler and Engel-Siegel 1984). In spite of Technomyrmex vitiensis having workers with the lowest number of metapleural gland cells, the gland is also present in the males. This species moreover contains both winged and wingless males (Pech and Bezděk 2016), of which the gland in the wingless individuals has approx. 4 cells per side, while the winged males only have 2 cells on average. Although both male morphs have a very small atrium, the wingless males do have dispenser bristles inside the atrium, whereas these are absent in the winged males. Wingless males live in the colony during the whole year in some Technomyrmex species including T. vitiensis, often in large numbers (Tsuji and Yamauchi 1994; Yamauchi et al. 1991; Pech and Bezděk 2016). These males were not observed to participate in brood care, but their metapleural gland secretion may contribute to the antimicrobial defense of the colony. On the other hand, winged males stay in the colony only for a short time. Also 
173 the life expectancy of wingless males is longer than that of winged males (Tsuji and

174 Yamauchi 1994; Pech and Bezděk 2016). Thus, the development of metapleural glands in 175 both male morphs may illustrate their contribution to the colony sanitation, their life 176 expectancy, or both.

\section{Acknowledgements}

178 We are grateful to An Vandoren for making the histological sections and to Alex Vrijdaghs 179 for his assistance with scanning microscopy. We also thank two anonymous reviewers for 180 making valuable comments on the manuscript. This research was supported by Research 181 Project N²104, 2015 and N²114, 2014 from the University of Hradec Králové.

\section{References}

Angus CJ, Jones MK, Beattie AJ (1993) A possible explanation for size differences in the metapleural glands of ants (Hymenoptera: Formicidae). J Austr Entomol Soc 32:73-77

Beattie AJ, Turnbull CL, Hough T, Knox RB (1986) Antibiotic production: a possible function for the metapleural glands of ants (Hymenoptera: Formicidae). Annls Entomol Soc Amer 79:448-450

Billen J, Šobotník J (2015) Insect exocrine glands. Arthr Struct Dev 44:399-400

Billen J, Hashim R, Ito F (2011) Functional morphology of the metapleural gland in the ant Crematogaster inflata (Hymenoptera, Formicidae). Invert Biol 130:277-281

Bolton B (2007) Taxonomy of the dolichoderine ant genus Technomyrmex Mayr

Bot ANM, Boomsma JJ (1996) Variable metapleural gland size-allometries in Acromyrmex leafcutter ants (Hymenoptera: Formicidae). J Kansas Entomol Soc 69:375-383 
Brown WL Jr (1968) An hypothesis concerning the function of the metapleural glands in ants. Amer Nat 102:188-191

Fanfani A, Valcurone Dazzini M (1991) Metapleural glands of some Dolichoderinae ants. Ethol Ecol Evol 3 (Suppl issue):95-98

Fernández-Marín H, Zimmerman JK, Rehner SA, Wcislo WT (2006) Active use of the metapleural glands by ants in controlling fungal infection. Proc R Soc B: Biol Sci 273:1689-1695

Hölldobler B, Engel-Siegel H (1984) On the metapleural gland of ants. Psyche 91:201-224

Maschwitz U (1974) Vergleichende Untersuchungen zur Funktion der Ameisenmetathorakaldrüse. Oecologia 16:303-310

Maschwitz U, Koob K, Schildknecht H (1970) Ein Beitrag zur Funktion der Metapleuraldrüse der Ameisen. J Insect Physiol 16:387-404

Noirot C, Quennedey A (1974) Fine structure of insect epidermal glands. Annu Rev Entomol 19:61-80

Oettler J, Heinze J (2009) Polymorphism of female reproductives in the tramp ant Technomyrmex vitiensis (Hymenoptera: Formicidae: Dolichoderinae). Myrmecol News $12: 133-137$

Pech P, Bezděk A (2016) Ergatomorph wingless males in Technomyrmex vitiensis Mann, 1921 (Hymenoptera: Formicidae). J Hym Res 53:25-34

Pospischil R (2011) Role of tropical greenhouses for introduction and establishment of foreign ant species (Hymenoptera: Formicidae) in central Europe. In: Robinson WH and de Carvalho Campos AE (eds). Proc 7th Int Conf Urban Pests. Inst Biol São Paulo, SP Brasil, pp 59-66

Schoeters E, Billen J (1993) Anatomy and fine structure of the metapleural gland in Atta (Hymenoptera, Formicidae). Belg J Zool 123:19-27

Stürup M, Baer B, Boomsma JJ (2014) Short independent lives and selection for maximal 

sperm survival make investment in immune defences unprofitable for leaf-cutting ant 223 males. Behav Ecol Sociobiol 68:947-955

224 Tragust S (2016) External immune defence in ant societies (Hymenoptera: Formicidae): 225 the role of antimicrobial venom and metapleural gland secretion. Myrmecol News $226 \quad 23: 119-128$

227 Tsuji K, Yamauchi K (1994) Colony level sex allocation in a polygynous and polydomous 228 ant. Behav Ecol Sociobiol 34:157-167

229 Yamauchi K, Furukawa T, Kinomura K, Takamine H, Tsuji K (1991) Secondary polygyny by 230 inbred wingless sexuals in the dolichoderine ant Technomyrmex albipes. Behav Ecol $231 \quad$ Sociobiol 29:313-319

232 Yek SH, Mueller UG (2011) The metapleural gland of ants. Biol Rev 86:774-791 


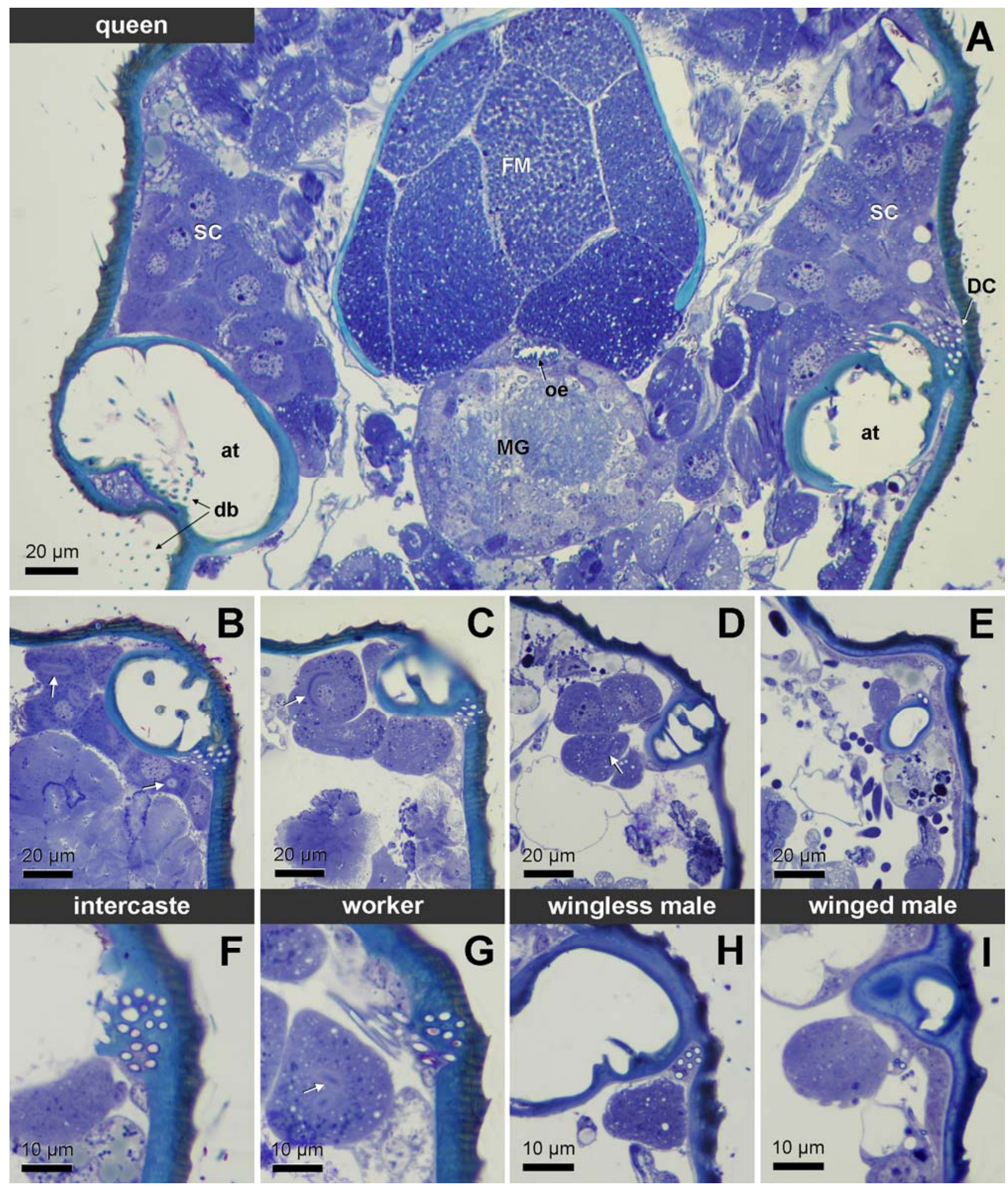

Fig. 1. Semithin cross sections through the metapleural gland: A. General view of thorax showing both glands in alate queen (at: atrium, db: dispenser bristles, DC: duct cells, FM: flight muscles, MG: metathoracic ganglion, oe: oesophagus, SC: secretory cells). B-E: Representative views of the right metapleural gland in the other castes (A-E all shown at same magnification). F-I: Cross section details of duct cells in region where ducts converge before opening into the atrium. Small white arrows indicate end apparatus in secretory cells. 

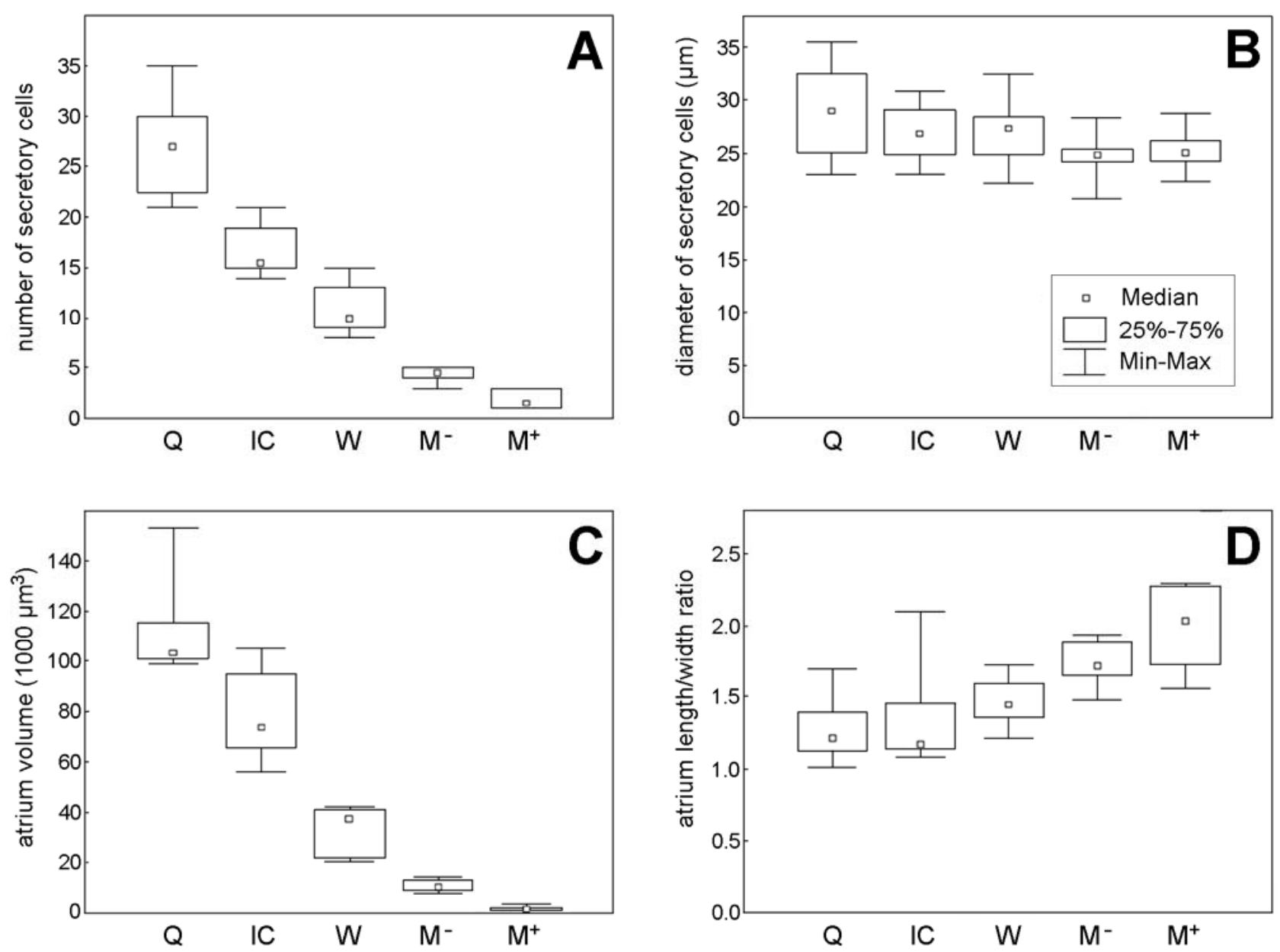

Fig. 2. Graphical comparison of the metapleural gland characteristics in the various castes $\left(\mathrm{Q}\right.$ : queens, IC: intercastes, $\mathrm{W}$ : workers, $\mathrm{M}^{-}$: wingless males, $\mathrm{M}^{+}$: alate males): $\mathbf{A}$. Number of secretory cells,

B. Size of secretory cells,

C. Atrium volume, Length/width ratio of atrium. 

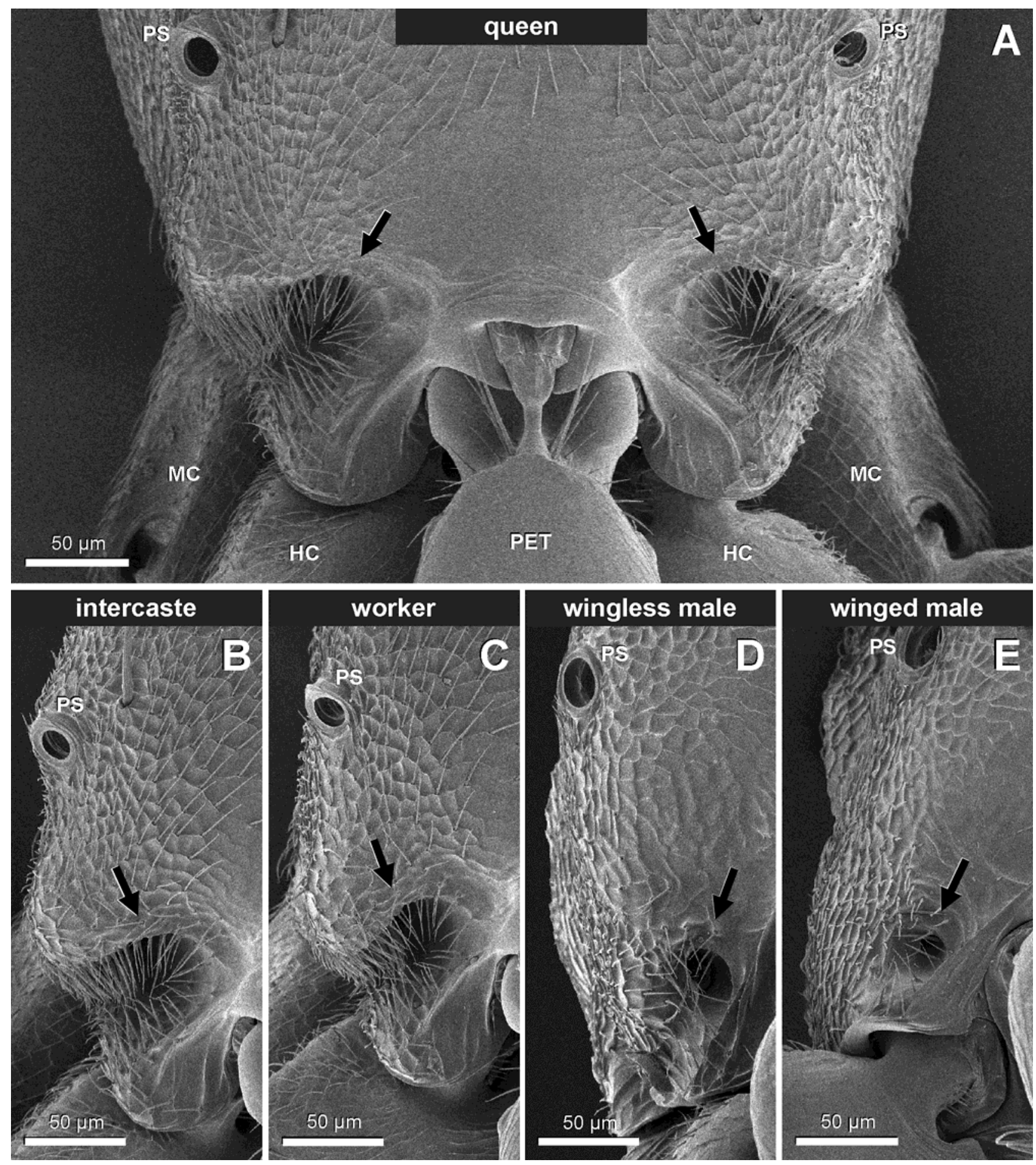

247 Fig. 3. Scanning micrographs showing the metapleural gland opening in the various 248 castes, seen from behind after removal of the gaster. A. General view of the posterior 249 thorax of a queen showing both metapleural gland openings (arrows). B-E. Views of 250 the left metapleural gland opening in the other castes (A-E all shown at same 251 magnification and orientation). HC: hindleg coxa, MC: midleg coxa, PET: petiole, PS: 252 propodeal spiracle. 


\section{Table legend}

256 Table 1. Significance of the differences in selected metapleural gland parameters among shown in bold.

Table 1. Significance of the differences in selected metapleural gland parameters among the castes of Technomyrmex vitiensis. Significant and nearly significant differences are shown in bold.

\begin{tabular}{|c|c|c|c|c|c|c|}
\hline Parameter & Caste & Queen & Intercaste & Worker & Wingless male & Winged male \\
\hline \multirow{5}{*}{ Cell number } & Queen & & $>>0.05$ & $>>0.05$ & $<0.01$ & $<0.01$ \\
\hline & Intercaste & $>>0.05$ & & $>>0.05$ & $>>0.05$ & $<0.01$ \\
\hline & Worker & $>>0.05$ & $>>0.05$ & & $>>0.05$ & $>>0.05$ \\
\hline & Wingless male & $<0.01$ & $>>0.05$ & $>>0.05$ & & $>>0.05$ \\
\hline & Winged male & $<0.01$ & $<0.01$ & $>>0.05$ & $>>0.05$ & \\
\hline \multirow{5}{*}{ Cell diameter } & Queen & & $>>0.05$ & $>>0.05$ & 0.043 & 0.063 \\
\hline & Intercaste & $>>0.05$ & & $>>0.05$ & $>>0.05$ & $>>0.05$ \\
\hline & Worker & $>>0.05$ & $>>0.05$ & & $>>0.05$ & $>>0.05$ \\
\hline & Wingless male & 0.043 & $>>0.05$ & $>>0.05$ & & $>>0.05$ \\
\hline & Winged male & 0.063 & $>>0.05$ & $>>0.05$ & $>>0.05$ & \\
\hline \multirow{5}{*}{ Atrium volume } & Queen & & $>>0.05$ & 0.045 & $<0.01$ & $<0.01$ \\
\hline & Intercaste & $>>0.05$ & & $>>0.05$ & 0.075 & $<0.01$ \\
\hline & Worker & 0.045 & $>>0.05$ & & $>>0.05$ & $>>0.05$ \\
\hline & Wingless male & $<0.01$ & 0.075 & $>>0.05$ & & $>>0.05$ \\
\hline & Winged male & $<0.01$ & $<0.01$ & $>>0.05$ & $>>0.05$ & \\
\hline \multirow{5}{*}{$\begin{array}{l}\text { Width/length } \\
\text { ratio atrium }\end{array}$} & Queen & & $>>0.05$ & $>>0.05$ & 0.085 & $<0.01$ \\
\hline & Intercaste & $>>0.05$ & & $>>0.05$ & $>>0.05$ & $<0.01$ \\
\hline & Worker & $>>0.05$ & $>>0.05$ & & $>>0.05$ & $>>0.05$ \\
\hline & Wingless male & 0.085 & $>>0.05$ & $>>0.05$ & & $>>0.05$ \\
\hline & Winged male & $<0.01$ & $<0.01$ & $>>0.05$ & $>>0.05$ & \\
\hline
\end{tabular}

